\title{
Application of Polyacrylamide for Methylene Blue Removal from Aqueous Solutions
}

\author{
Hassan Zavvar Mousavi", Aisan Khaligh, Mahdi Behzad and Jalal Rahchamani
}

\author{
Department of Chemistry, Semnan University, Semnan, Iran
}

\begin{abstract}
In this study the removal of methylene blue (MB) dye from aqueous solutions by polyacrylamide (PAA) as a potential adsorbent was reported. PAA was characterized using SEM and FTIR measurements. Batch adsorption experiments were performed as a function of the solution $\mathrm{pH}$, contact time, solute concentration and temperature. Evaluation of the obtained data with isotherm studies indicated that the adsorption process was matched well with the Langmuir model. The maximum capacity of adsorbent for MB was $111.1 \mathrm{mg} \mathrm{g}^{-1}$. Kinetic studies were carried out on various kinetic models and the pseudo-second order kinetic model was fitted very well with experimental data. Moreover, the thermodynamic parameters indicated that the adsorption reaction was endothermic and spontaneous process.
\end{abstract}

Keywords: Polyacrylamide, Removal, Methylene blue, Isotherm, Kinetic.

\section{INTRODUCTION}

Dye-contaminated wastewater, its treatment and disposal is a serious environmental problem which is faced by the textile, dye synthesis, printing, paper, rubber, cosmetic, food and related industries [1, 2]. Over 10,000 dyes with an annual production of $7 \times 10^{5}$ tons worldwide have been reported to be commercially available [3]. Dyes are usually synthetic materials. They have complex aromatic molecular structures. Most of them are stable and are not easily biodegraded. Dyes are usually harmful materials and most of the organic dyes and their products have a mutagenic or carcinogenic effect on human beings. As a result, greater attention must be paid to their treatment before their discharge [2].

Methylene blue (MB) is a thiazine cationic dye. It has found wide applications in several industries such as cottons or wools dyeing and paper coloring [4]. Though MB is not a strongly hazardous material but it is potentially able to have some harmful effects. It is reported that the exposure to MB may cause mental confusion, increased heart rate, vomiting and several other problems for humans [4-6]. Owing to these harmful effects on humans, the removal of $M B$ from industrial effluents has become one of the major environmental concerns.

Many physical, chemical, and even biological processes have been investigated for the removal of dyes from aquatic environments, including oxidation and sonochemical degradation [7], photocatalytic degradation [8], coagulation [9], photochemical and

*Address correspondence to this author at the Department of Chemistry, Semnan University, Semnan, Iran; Tel: +98- 231-3354057; Fax: +98-2313354110; E-mail: hzmousavi@semnan.ac.ir sonochemical combined processes [10], photocatalytic and electrochemical combined treatment [11], electrocoagulation [12], photo-Fenton processes [13], ozonation [14] and adsorption [15-18]. Among these approaches, adsorption is generally preferred due to its sludge free clean operation, high efficiency, ease of handling, low cost and availability of different adsorbents. Several adsorbents have been studied for their potential ability of adsorbing dyes from aqueous effluents, including rice husk [19], durian peel [20], rattan sawdust [21], modified chitosan [22], perlite [23], peanut husk [24], montmorillonite [25] and compost [26].

The development of new adsorbent for the removal of heavy metal ions, dyes and other toxic materials is the subject of great interest nowadays. These materials are supposed to have superior properties such as high adsorption capacities, fast adsorption rates and higher mechanical strength for water and wastewater treatment. Recently, the use of synthetic polymeric materials as new class of adsorbents with fair adsorption capacities is so considered [17, 27-30]. In this regard, Polyacrylamide (PAA) is one of the most widely used polymers. PAA has large numbers of amide side groups. It can be defined as water-swollen, three-dimensional networks which can absorb a large amount of water compared to other water absorbing materials. It has found wide applications in many fields, e.g. municipal water treatment, mineral processing and drag reduction [17, 31, 32].

In the present study, PAA was used to remove MB form aqueous solutions. The adsorption kinetics and thermodynamics, contact time, initial concentration of $\mathrm{MB}$, temperature and $\mathrm{pH}$ effects were investigated in batch mode. The analyses of equilibrium data have been done using different adsorption isotherms. 


\section{EXPERIMENTATION}

\subsection{Materials}

All chemicals were purchased from commercial sources and were used without further purification. Polyacrylamide was obtained from, Guangzhou Chemical Reagent Factory, Guangzhou, China. Stock solution of $\mathrm{MB}\left(\mathrm{C}_{16} \mathrm{H}_{18} \mathrm{~N}_{3} \mathrm{SCl}\right.$. $\left.3 \mathrm{H}_{2} \mathrm{O}, \lambda_{\max }=668 \mathrm{~nm}\right)$ was prepared by dissolving accurately weighted amount of dye in distilled water to the concentration of $1 \mathrm{~g} / \mathrm{L}$. The experimental solutions were obtained by diluting the dye stock solution with distilled water to the needed initial concentrations.

\subsection{Preparation of Adsorbent}

PAA was immersed in distilled water for $3 \mathrm{~h}$. The swollen gels were taken out at regular time intervals and were then wiped superficially with a filter paper, weighed and replaced in the same solution to ensure the state of equilibrium swelling.

\subsection{Batch Studies}

Removal experiments were performed using batch technique to obtain the adsorption rate and equilibrium data. A suspension containing $0.02 \mathrm{~g}$ of PAA was mixed by stirring $(125 \mathrm{rpm})$ with a $200 \mathrm{ml}$ aqueous solution of $\mathrm{MB}$ at a known initial concentration in an Erlenmeyer flask which was immersed in a bath in thermostated water keeping constant working temperature. The $\mathrm{pH}$ values of the solutions were adjusted by adding negligible amounts of $\mathrm{NaOH}$ or $\mathrm{HNO}_{3}$ solutions. An aliquot of the solution was withdrawn at the pre-determined time intervals, and was centrifuged at $4000 \mathrm{rpm}$ for $10 \mathrm{~min}$, then filtered through a What-man filter paper. The residual concentration of dye was subsequently determined in the filtrate using UV-Visible spectrophotometer at the wavelength of maximum absorbance. The adsorption tests were continued until the equilibrium concentration was reached. Effects of $\mathrm{pH}(2-10)$, contact time (25$240 \mathrm{~min})$, kinetic experiments $(50-300 \mathrm{mg} / \mathrm{L}$ initial MB concentration), adsorption isotherm $(50-300 \mathrm{mg} / \mathrm{L}$ initial MB concentration) and thermodynamic studies (298$318 \mathrm{~K}$ ) on adsorption were studied. All the experimental data were the averages of triplicate determinations.

For the experiments of adsorption kinetics, mentioned procedure with $200 \mathrm{ml}$ aqueous solution of $\mathrm{MB}$ at different initial concentrations $(50-300 \mathrm{mg} / \mathrm{L})$ was performed. The amount of $\mathrm{MB}$ adsorbed onto adsorbent was calculated using the following expression:

$\mathrm{q}_{\mathrm{t}}=\frac{\left(\mathrm{C}_{\mathrm{i}}-\mathrm{C}_{\mathrm{t}}\right)}{\mathrm{w}} \times \mathrm{V}$

where $q_{t}$ is the mass of adsorbed MB per unit mass of adsorbent $\left(\mathrm{mg} \mathrm{g}^{-1}\right) ; \mathrm{C}_{\mathrm{i}}$ and $\mathrm{C}_{\mathrm{t}}$ are the initial and actual concentration ( $\mathrm{mg} \mathrm{L}^{-1}$ ) of $\mathrm{MB}$ at time $\mathrm{t}$, respectively; $\mathrm{V}$ is the volume of the treated solution $(\mathrm{mL}) ; \mathrm{w}$ is the mass of adsorbent $(\mathrm{g})$.

\subsection{Characterization Methods}

The FTIR spectrum of polymeric adsorbent was recorded on a Shimadzu FTIR (model 8000 Series, Japan) spectrophotometer using $\mathrm{KBr}$ pellets. The microstructure of the PAA was examined using Hitachi (model: JSM-5600 imaging mode) scanning electron microscope (SEM). The absorption spectrum of the dye was recorded on a Shimadzu UV-Vis (model 1601, Japan) spectrophotometer. A Metrohm pH meter (model E-632) with a glass combination electrode was used for $\mathrm{pH}$ measurements.

\section{RESULTS AND DISCUSSION}

\subsection{Absorbent Characterization}

Scanning electron microscopy (SEM) was used to investigate the morphology of the PAA (Figure 1). As it could be seen from the SEM image, the PAA has very few small pores on the surface. The surface roughness could be considered as a factor providing an increase in the surface area.

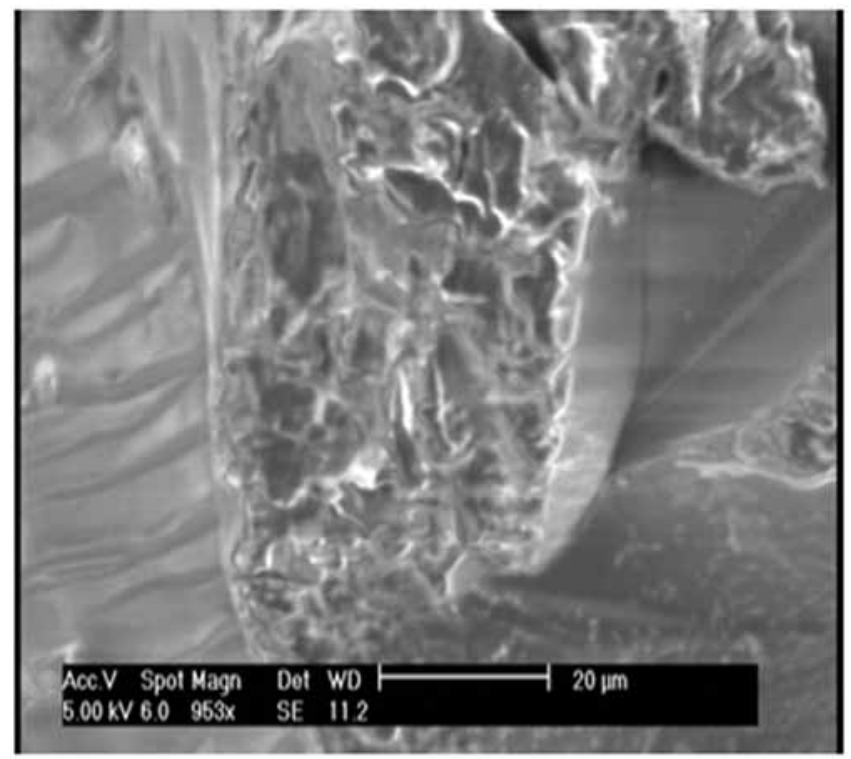

Figure 1: SEM image of polyacrylamide. 
The FTIR spectrum of PAA is displayed in Figure 2. The most significant feature of the spectrum is the appearance of two bands at around 3400 and $1690 \mathrm{~cm}^{-}$ ${ }^{1}$ which are assigned to $\mathrm{NH}_{2}$ and $\mathrm{C}=\mathrm{O}$ groups stretching vibration, respectively. Furthermore, the signals at around $3000 \mathrm{~cm}^{-1}$ are also assignable to the stretching vibrations of aliphatic $\mathrm{C}$-Hs. Since the FTIR frequencies of MB overlap with the FTIR frequencies of PAA, no further insight is obtained from the FTIR spectroscopy after the adsorption.

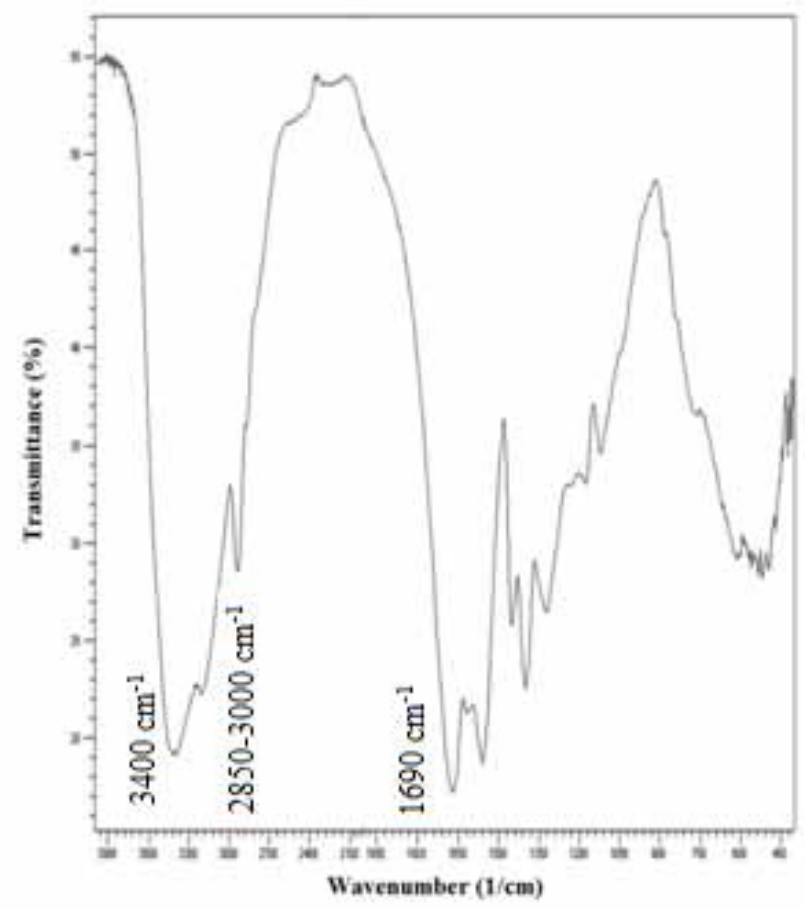

Figure 2: FTIR spectrum of polyacrylamide.

\subsection{Effect of $\mathrm{pH}$}

$\mathrm{pH}$ plays a significant role in affecting the extent of adsorption, particularly when the adsorbent and adsorbate, both are charged species [28]. In the current study the adsorbate MB is a cationic dye while the adsorbent PAA contains ionizable amine groups along polymer chains. The effect of $\mathrm{pH}$ on the adsorption of MB by PAA was studied over the $\mathrm{pH}$ range of $2-10$ with $100 \mathrm{mg} / \mathrm{L}$ initial concentration of MB. As could be seen from Figure 3, the adsorption is low at lower $\mathrm{pH}$ values. But as the $\mathrm{pH}$ increases, a significant increase in the adsorption is observed. Our results showed that the optimized $\mathrm{pH}$ range for the removal of MB was between 8 and 10 .

$M B$ is a dye which dissociates in water solution followed by a cationic hydrolysis in the next steps. The adsorption process happens mainly because of electrostatic attractions with amide groups in the adsorbent. However, at lower pHs more protons will protonate $\mathrm{NH}_{2}$ groups of PAA to form $\mathrm{NH}_{3}{ }^{+}$. ,- $-\mathrm{NH}-3$ + . So they would be unable to adsorb dye molecules and poor adsorption may only be due to $\mathrm{H}$-bonding interactions between $\mathrm{N}$ and $\mathrm{S}$ atoms of $\mathrm{MB}$ molecules and $\mathrm{H}$ atoms from $\mathrm{NH}_{2}$ groups of polymeric adsorbent. Therefore, at higher pHs The available $\mathrm{NH}_{2}$ groups will interact with dye molecule and adsorption will occur. Similar results have also been reported [17, 27, 32, 33].

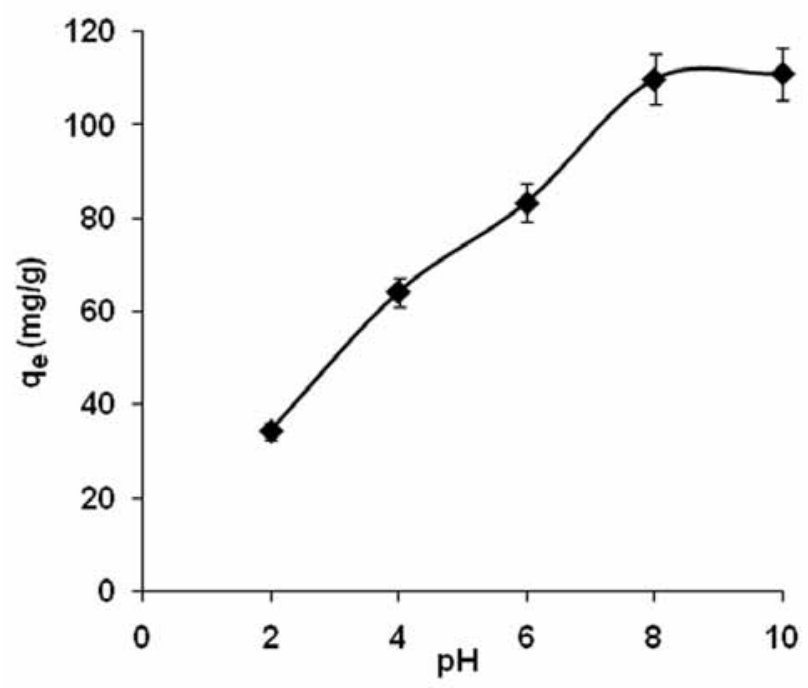

Figure 3: Effect of initial pH on MB adsorption by PAA (initial $\mathrm{MB}$ concentration $100 \mathrm{mg} / \mathrm{L} ; 0.1 \mathrm{~g} / \mathrm{L}$ of $\mathrm{PAA}$, agitation speed $125 \mathrm{rpm}$; contact time $120 \mathrm{~min}$; temperature $298 \mathrm{~K}$ ).

\subsection{Effects of Contact Time}

Equilibrium time is another important parameter to dyes wastewater treatment process. The effect of the contact time on the adsorption capacity of PAA for MB with known initial concentrations, the dosage of $0.1 \mathrm{~g} / \mathrm{L}$, and $\mathrm{pH}$ of 8 were described in Figure 4 . It is clear that the adsorption rate of $\mathrm{MB}$ increased with time and adsorption equilibrium was obtained after stirring for 120 min with initial MB concentrations of $50-300 \mathrm{mg}$ $\mathrm{L}^{-1}$. Not much benefit was obtained from stirring longer than $120 \mathrm{~min}$; therefore, the adsorption time was fixed at $120 \mathrm{~min}$ in the subsequent adsorption experiments. The initial rate of MB adsorption was fast. This could be explained by the fact that large numbers of adsorption sites of the PAA were available at the beginning but afterwards, slower adsorption rates were seen which were obviously due to the saturation of active sites. The initial concentrations of MB were also important. As the initial concentrations increased from 50 to 300 $\mathrm{mg} \mathrm{L}^{-1}$, the amount of adsorbed MB also increased up to $1200 \mathrm{mg} \mathrm{g}^{-1}$. The increase in the driving force of the 
concentration gradient could have resulted in the overcome to the mass transfer resistance of the MB molecules between the aqueous phases and the solid phases with the increase in the initial concentration.

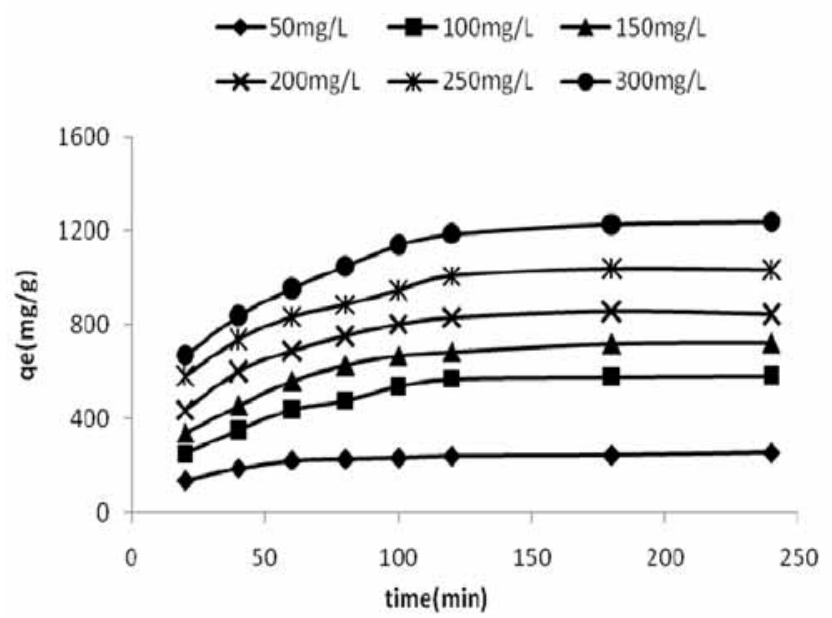

Figure 4: Effect of contact time on $M B$ adsorption by PAA (initial MB concentration $5-300 \mathrm{mg} / \mathrm{L} ; 0.1 \mathrm{~g} / \mathrm{L}$ of $\mathrm{PAA} ; \mathrm{pH}=8$; agitation speed125 rpm; temperature $298 \mathrm{~K}$ ).

\subsection{Effect of Temperature}

To investigate the temperature effect on the adsorption of $\mathrm{MB}$, the equilibrium adsorption studies were carried out at 298, 308 and $318 \mathrm{~K}$. Obviously, the adsorption of MB on PAA increased with the rise in temperature from $298 \mathrm{~K}$ to $318 \mathrm{~K}$ (Figure 5), which suggested that the removal process was endothermic. This might be as a result of the increase in the mobility of the dye with increasing temperature [34]. An increasing number of molecules may also obtain sufficient energy to undertake the interaction with active sites of the surface. Furthermore, higher

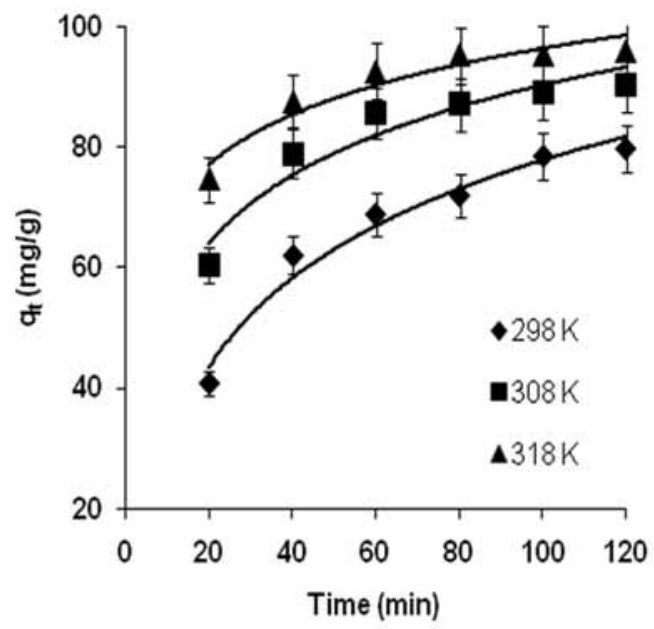

Figure 5: Effect of Temperature on $M B$ adsorption by PAA (initial MB concentration $100 \mathrm{mg} / \mathrm{L} ; 0.1 \mathrm{~g} / \mathrm{L}$ of $\mathrm{PAA} ; \mathrm{pH}=8$; agitation speed125 rpm; contact time $120 \mathrm{~min}$ ). temperatures may produce a swelling effect within the internal structure of the PAA which enables larger dyes to further penetrate $[35,36]$.

\subsection{Adsorption Isotherms Studies}

Adsorption isotherms play an important role in the analysis and design of the adsorption systems. In the present study, the experimental equilibrium adsorption data were tested using Langmuir, Freundlich and Tempkin isotherm models.

Langmuir adsorption isotherm is valid in the case of monolayer adsorption onto the surface with a finite number of identical sites. The Linear Langmuir equation is given below [37]:

$\frac{\mathrm{C}_{\mathrm{e}}}{\mathrm{q}_{\mathrm{e}}}=\frac{1}{\mathrm{~K}_{\mathrm{L}} \mathrm{q}_{\max }}+\frac{\mathrm{C}_{\mathrm{e}}}{\mathrm{q}_{\max }}$

Where $q_{e}$ is the amount of $M B$ adsorbed at equilibrium ( $\left.\mathrm{mg} \mathrm{g}^{-1}\right), \mathrm{q}_{\max }$ the maximum adsorption capacity corresponding to complete monolayer coverage on the surface $\left(\mathrm{mg} \mathrm{g}^{-1}\right), C_{e}$ the equilibrium concentration of $M B$ in solution $\left(\mathrm{mg} \mathrm{L}^{-1}\right)$, and $\mathrm{K}_{\mathrm{L}}$ is the Langmuir constant $\left(\mathrm{L} \mathrm{mg}^{-1}\right)$, related to the free energy of adsorption. Linear plots of $C_{e} / q_{e}$ versus $C_{e}$ were employed to determine the values of $\mathrm{q}_{\max }$ and $\mathrm{K}_{\mathrm{L}}$ (Figure 6). The data obtained with the correlation coefficients $\left(R^{2}\right)$ were listed in Table 1 .

The Langmuir equation can be re-expressed in term of a dimensionless factor, $R_{L}$, which predicts whether an adsorption system is favorable or unfavorable. $R_{L}$ is defined as follows [38]:

$\mathrm{R}_{\mathrm{L}}=\frac{1}{1+\mathrm{K}_{\mathrm{L}} \mathrm{C}_{0}}$

$\mathrm{C}_{0}\left(\mathrm{mg} \mathrm{L}^{-1}\right)$ is the highest initial solute concentration and $K_{L}$ is the Langmuir constant $\left(L \mathrm{mg}^{-1}\right)$. $R_{L}$ values between 0 and 1 indicate favorable adsorption. The $R_{L}$ value in the present study has been found to be 0.2 , which is an indication of the favorable adsorption of MB dye on the adsorbent.

The Freundlich isotherm model is an empirical equation which is applicable to describe heterogeneous systems. This is characterized by a factor named as the heterogeneity factor $1 / \mathrm{n}$. Freundlich isotherm is used for the description of multilayer adsorption with interaction between adsorbed molecules. The linear Freundlich equation is expressed as follows [39]: 


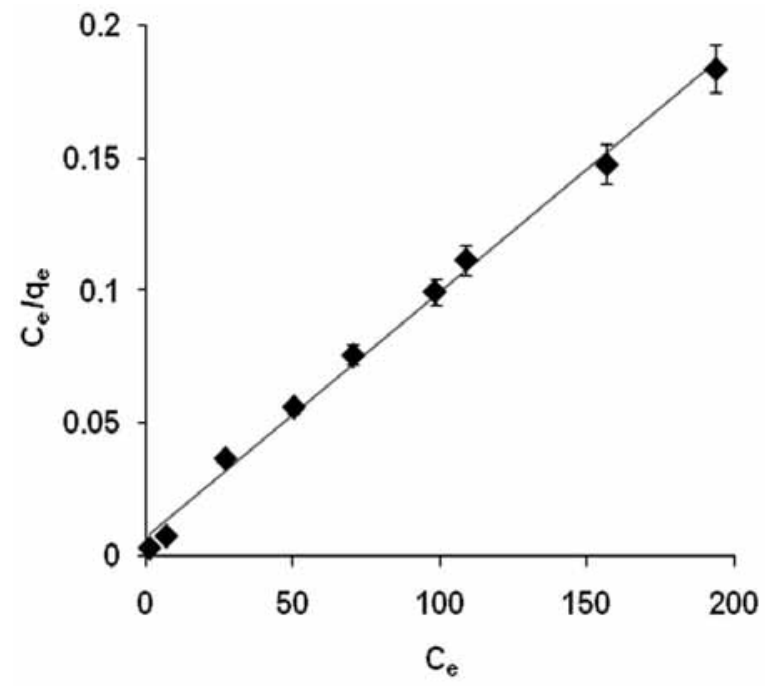

Figure 6: Langmuir plots for $\mathrm{MB}$ adsorption on $\mathrm{PAA}$ (initial MB concentration $50-300 \mathrm{mg} / \mathrm{L} ; 0.1 \mathrm{~g} / \mathrm{L}$ of $\mathrm{PAA} ; \mathrm{pH}=8$; temperature $298 \mathrm{~K}$ ).

$\operatorname{lnq}_{\mathrm{e}}=\ln \mathrm{K}_{\mathrm{F}}+1 / \mathrm{n} \ln \mathrm{C}_{\mathrm{e}}$

Where $\mathrm{K}_{\mathrm{F}}$ and $\mathrm{n}$ are Freundlich isotherm constants which are related to adsorption capacity $\left(\mathrm{mg}^{1-n} \mathrm{~L}^{\mathrm{n}} \mathrm{g}^{-1}\right)$ and adsorption intensity, respectively. A plot of $\ln \left(q_{e}\right)$, q-e. versus $\ln \left(\mathrm{C}_{\mathrm{e}}\right)$ enables the constant $\mathrm{K}_{\mathrm{F}}$ and $\mathrm{n}$ to be determined. It is clear from Table 1 that the values of $n$ were greater than 1 , while $\mathrm{n}>1$ represent favorable adsorption condition [40].

There are two important assumptions in Tempkin isotherm model: (i) some indirect adsorbate/adsorbate interactions decreases the adsorption energy linearly as a result of the surface coverage and (ii) a uniform distribution of binding energies characterizes the adsorption, up to some maximum binding energy [41, 42]. The linear form of Tempkin isotherm model is given as:

$\mathrm{q}_{\mathrm{e}}=\mathrm{B}_{\mathrm{T}} \ln \mathrm{K}_{\mathrm{T}}+\mathrm{B}_{\mathrm{T}} \ln \mathrm{C}_{\mathrm{e}}$

Where $\mathrm{K}_{\mathrm{T}}$ is the equilibrium binding constant related to the maximum binding energy $\left(L \mathrm{mg}^{-1}\right)$. The $\mathrm{B}_{T}$ is constant related to the heat of adsorption $\left(\mathrm{kJ} \mathrm{mol}^{-1}\right)$. The determination of the isotherm constants $\mathrm{B}_{T}$ and $\mathrm{K}_{\mathrm{T}}$ could be achieved from the slope and the intercept of the plot of $\mathrm{q}_{\mathrm{e}}$ versus $\ln \mathrm{C}_{\mathrm{e}}$, respectively.

The data obtained with the correlation coefficients $\left(R^{2}\right)$ for all the adsorption isotherms were presented in Table 1. Comparison of the linear isotherm plots shows that the Langmuir model yielded a much better fit than the other studied models. This indicates the homogeneous nature of PAA surface which means that

Table 1: Isotherm Parameters for MB Adsorption on PAA at $298 \mathrm{~K}$

\begin{tabular}{|c|c|c|c|c|c|c|c|c|}
\hline \multicolumn{3}{|c|}{ Langmuir isotherm } & \multicolumn{3}{c|}{ Freundlich isotherm } & \multicolumn{3}{c|}{ Tempkin isotherm } \\
\hline $\mathbf{q}_{\max }$ & $\mathbf{K}_{\mathbf{L}}$ & $\mathbf{R}^{2}$ & $\mathbf{K}_{\mathbf{F}}$ & $\mathbf{n}$ & $\mathbf{R}^{2}$ & $\mathbf{K}_{\mathbf{T}}$ & $\mathbf{B}_{\mathbf{T}}$ & $\mathbf{R}^{2}$ \\
\hline \hline 111.1 & 0.112 & 0.999 & 457 & 6.71 & 0.988 & 59.5 & 107.5 & 0.955 \\
\hline
\end{tabular}

Table 2: Comparison of Adsorption Capacities of Various Adsorbents for the Removal of MB

\begin{tabular}{|l|c|c|}
\hline Adsorbent & $\mathbf{q}_{\max }\left(\mathbf{m g ~ g}^{-1}\right)$ & Reference \\
\hline \hline Algal biomass & 171 & 43 \\
\hline Fibrous clay & 85.0 & 44 \\
\hline Orange peel & 17.6 & 45 \\
\hline Spent activated clay & 78 & 46 \\
\hline Shaddock peel & 305.8 & 47 \\
\hline Activated carbon & 412 & 1 \\
\hline Coir pith carbon & 5.8 & 48 \\
\hline Spent cottonseed hull & 185.2 & 49 \\
\hline Poly(vinyl acetate) & 2.612 & 50 \\
\hline Poly( acrylamide-co-maleic acid) & 2.2 & 51 \\
\hline Polyacrylamide grafted attapulgite & 9.27 & 52 \\
\hline Polyacrylamide & 111.1 & Present study \\
\hline
\end{tabular}


each dye molecule/PAA adsorption has equal adsorption activation energy. Therefore uptake of $M B$ preferably follows the monolayer adsorption process.

A comparison of the maximum adsorption capacities of different adsorbents for MB dye removal was also reported in Table 2. It is clear from this table that the adsorption capacity of PAA used in the present study is significant. Therefore, PAA is considered to be excellent and potential adsorbent for dyes removal from aqueous solutions.

\subsection{Kinetic Studies}

The dynamics of the adsorption process in terms of the order and the rate constant can be evaluated using the kinetic adsorption data. The kinetics of $M B$ adsorption on PAA was analyzed using pseudo-firstorder, pseudo-second-order and intra-particle diffusion models. The correlation coefficient $\left(R^{2}\right.$, close or equal to 1 ) is used to evaluate the suitability of different models. The linearized-integral forms of studied kinetic models are expressed as [53, 54, 55]:

$\ln \left(\mathrm{q}_{1}-\mathrm{q}_{\mathrm{t}}\right)=\ln \mathrm{q}_{1}-\mathrm{k}_{1} \mathrm{t}$

$\frac{\mathrm{t}}{\mathrm{q}_{\mathrm{t}}}=\frac{1}{\mathrm{k}_{2} \mathrm{q}_{2}^{2}}+\frac{\mathrm{t}}{\mathrm{q}_{2}}$

$\mathrm{q}_{\mathrm{t}}=\mathrm{k}_{\mathrm{i}} \mathrm{t}^{1 / 2}+\mathrm{C}$

(8)

Where $q_{1}\left(\right.$ or $\left.q_{2}\right)$ and , $q-t . q_{t}\left(m^{-1}\right)$ are the values of amount adsorbed per unit mass of sorbent at equilibrium and at any time t. $\mathrm{k}_{1}\left(\mathrm{~L} \mathrm{~min}^{-1}\right)$ is the pseudofirst-order adsorption rate coefficient. $k_{2}(\mathrm{~g} / \mathrm{mg} \mathrm{min})$ is the pseudo-second-order constant. The values of $k_{2}$ at different initial dye concentrations were calculated from the slopes of the respective linear plots of $t / q_{t} v s$. $t$ (Figure 7). $\mathrm{k}_{\mathrm{i}}\left(\mathrm{mg} / \mathrm{g} \mathrm{min}^{1 / 2}\right)$ is the diffusion rate coefficient and $C$ is the intercept and relate to the thickness of the boundary layer. The parameter values for each model were obtained from the respective fitting curve resulting from the linear form of pseudofirst order, pseudo-second order and intra-particle diffusion kinetic equations. The results were listed in Table 3 along with the correlation coefficient. It can be seen that pseudo-second-order kinetic model provides a good correlation $\left(R^{2}\right.$, close to 1$)$ for the adsorption of MB dye at all initial dye concentrations. What is more, the $q_{2}$ values, calculated by pseudo-second-order model, represent a fine agreement with the detected values in experiment. This clearly indicates that the pseudo-second order model, an indication of the chemisorptions mechanism, is able to describe properly the kinetic behavior of MB adsorption on PAA.

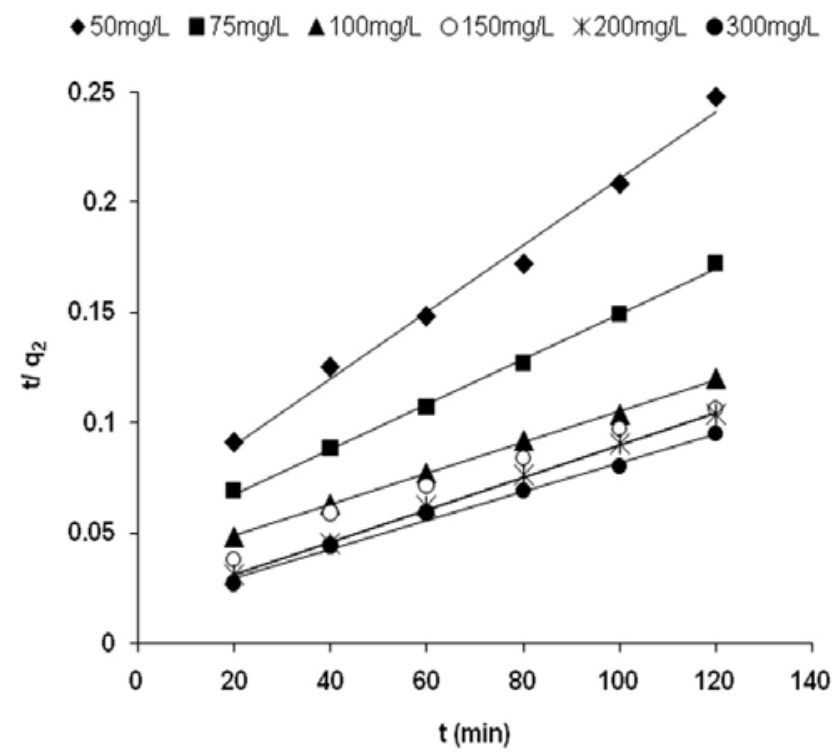

Figure 7: Pseudo-second-order kinetics plots for $M B$ adsorption on PAA (initial MB concentration $50-300 \mathrm{mg} / \mathrm{L} ; 0.1$ $\mathrm{g} / \mathrm{L}$ of PAA; $\mathrm{pH}=8$; temperature $298 \mathrm{~K}$ ).

\subsection{Thermodynamic Studies}

Thermodynamic studies are used to decipher any reaction in a better way. In the present study also, the variation in the extent of adsorption with respect to temperature has been explained based on thermodynamic parameters viz. Gibbs free energy $\left(\Delta G^{0}\right)$, enthalpy $\left(\Delta H^{0}\right)$ and entropy $\left(\Delta S^{0}\right)$. Thermodynamic parameters were obtained at different temperatures $(298-318 \mathrm{~K}$ ) according to the following formulas:

$\mathrm{K}_{\mathrm{C}}=\frac{\mathrm{q}_{\mathrm{e}}}{\mathrm{C}_{\mathrm{e}}}$

$\Delta \mathrm{G}^{0}=-\mathrm{RT} \ln \mathrm{K}_{\mathrm{C}}$

$\operatorname{Ln} \mathrm{K}_{\mathrm{C}}=\frac{\Delta \mathrm{S}^{0}}{\mathrm{R}}-\frac{\Delta \mathrm{H}^{0}}{\mathrm{RT}}$

Where $K_{C}$ is the equilibrium constant, $R$ is the universal gas constant $(8.314 \mathrm{~J} / \mathrm{mol} \mathrm{K})$ and $\mathrm{T}$ is the absolute temperature $(\mathrm{K}) . \Delta \mathrm{H}^{0}$ and $\Delta \mathrm{S}^{0}$ were obtained from slope and intercept of the plot of $L n K_{C}$ versus $1 / T$. The values of the thermodynamic parameters were recorded in Table 4. Positive $\Delta \mathrm{H}^{0}$ values at different temperatures showed the endothermic nature of 
Table 3: Kinetic Parameters for MB Adsorption on PAA at $298 \mathrm{~K}$

\begin{tabular}{|c|c|c|c|c|c|c|c|c|c|}
\hline \multirow[b]{2}{*}{$\begin{array}{c}C_{0} \\
(m g / L)\end{array}$} & \multirow[b]{2}{*}{$\begin{array}{c}q_{e}(\exp .) \\
(\mathrm{mg} / \mathrm{g})\end{array}$} & \multicolumn{3}{|c|}{ Pseudo first-order model } & \multicolumn{3}{|c|}{ Pseudo second-order model } & \multicolumn{2}{|c|}{$\begin{array}{c}\text { Intra-particle diffusion } \\
\text { model }\end{array}$} \\
\hline & & $\begin{array}{l}q_{1}(\text { cal. }) \\
\left(\mathrm{mg} \mathrm{g}^{-1}\right)\end{array}$ & $\mathrm{K}_{1}$ & $\mathbf{R}^{2}$ & $\begin{array}{c}q_{2} \text { (cal.) } \\
\left(\mathrm{mg} \mathrm{g}^{-1}\right)\end{array}$ & $\mathrm{K}_{2}$ & $\mathbf{R}^{2}$ & $\mathbf{k}_{\mathbf{i}}$ & $\mathbf{R}^{2}$ \\
\hline 50 & 482 & 1267 & 0.055 & 0.939 & 662 & $3.82 \times 10^{-5}$ & 0.998 & 44.01 & 0.938 \\
\hline 75 & 695 & 841 & 0.029 & 0.993 & 970 & $2.27 \times 10^{-5}$ & 0.998 & 70.43 & 0.973 \\
\hline 100 & 998 & 1233 & 0.029 & 0.958 & 1408 & $1.47 \times 10^{-5}$ & 0.999 & 92.76 & 0.974 \\
\hline 200 & 1150 & 920 & 0.027 & 0.986 & 1370 & $3.20 \times 10^{-5}$ & 0.999 & 115.4 & 0.971 \\
\hline 300 & 1255 & 1815 & 0.041 & 0.881 & 1538 & $2.56 \times 10^{-5}$ & 0.992 & 123.3 & 0.967 \\
\hline
\end{tabular}

Table 4: Thermodynamic Parameters for MB Adsorption on PAA at Different Temperatures

\begin{tabular}{|c|c|c|c|c|}
\hline$\Delta \mathbf{H}^{\mathbf{0}}(\mathbf{k J} / \mathbf{m o l})$ & $\Delta \mathbf{S}^{0}(\mathbf{k J} / \mathbf{m o l ~ K})$ & \multicolumn{3}{|c|}{$\Delta \mathbf{G}^{0}(\mathbf{k J} / \mathbf{m o l})$} \\
\hline \hline 69.57 & 263 & $298 \mathrm{~K}$ & $308 \mathrm{~K}$ & $318 \mathrm{~K}$ \\
\hline & & -9.14 & -12.75 & -14.15 \\
\hline
\end{tabular}

adsorption process, which was supported by the increasing adsorption of $\mathrm{MB}$ dye with the increase in temperature. While negative values of $\Delta G^{0}$ indicated that the adsorption of MB was spontaneous process under the conditions applied. Positive values of $\Delta S^{0}$ were indicative of increased randomness at the adsorbent-adsorbate interface.

The pseudo-second-order rate constant of dye adsorption is expressed as a function of temperature by the Arrhenius type relationship:

$\ln \mathrm{K}_{2}=\ln \mathrm{A}-\frac{\mathrm{E}_{\mathrm{a}}}{\mathrm{RT}}$

Where $E_{a}$ is the Arrhenius activation energy of sorption, representing the minimum energy that reactants must have for the reaction to proceed; $A$ the Arrhenius factor; $R$ the gas constant; $T$ is the solution temperature. When Ink $_{2}$ is plotted versus $1 / \mathrm{T}$, a straight line with slope $-E_{a} / R$ is obtained. The chemisorption or physisorption mechanisms are often an important indicator to describe the type of interaction between dye molecule and adsorbent. The physisorption processes usually have energies in the range of 4-40 $\mathrm{kJ} / \mathrm{mol}$, while higher activation energies (40-400 $\mathrm{kJ} / \mathrm{mol}$ ) suggest chemisorption [56]. The value of $E_{\mathrm{a}}$ in this study was $61.9 \mathrm{~kJ} / \mathrm{mol}$ which indicates that $M B$ adsorption on PAA is chemical in nature

\section{CONCLUSION}

The present study indicated that PAA was an effective adsorbent for the removal of $M B$ from aqueous solutions. The batch study parameters, $\mathrm{pH}$ of solution, contact time and temperature, were found to be effective on the adsorption efficiency of MB dye. The kinetics and isotherm experiment data could be well described with the pseudo-second-order model and the Langmuir isotherm model, respectively. The maximum adsorption capacity of $111.1 \mathrm{mg} \mathrm{g}^{-1}$ was also obtained for $\mathrm{MB}$ at optimum conditions of $\mathrm{pH} 8$, temperature $298 \mathrm{~K}$ and contact time of 120 min with 0.1 $\mathrm{g} / \mathrm{L}$ of PAA. Base on thermodynamic studies, the adsorption reaction was spontaneous and endothermic in nature and the main strength of adsorption was the chemical adsorption.

\section{REFERENCES}

[1] Robinson $T$, McMullan $G$, Marchant $R$, Nigam $P$. Remediation of dyes in textile effluent: A critical review on current treatment technologies with a proposed alternative. Bioresour Technol 2001; 77: 247-55.

http://dx.doi.org/10.1016/S0960-8524(00)00080-8

[2] Aksu Z. Application of biosorption for the removal of organic pollutants: A review. Process Biochem 2005; 40: 997-1026. http://dx.doi.org/10.1016/j.procbio.2004.04.008

[3] Pearce CI, Lloyd JR, Guthre JT. The removal of colour from textile wastewater using whole bacterial cells: A review. Dyes Pigm 2003; 58: 179-96.

http://dx.doi.org/10.1016/S0143-7208(03)00064-0

[4] Hameed BH, Din ATM, Ahmad AL, Adsorption of methylene blue onto bamboo-basedactivated carbon: Kinetics and equilibrium studies. J Hazard Mater 2007; 141: 819-25. http://dx.doi.org/10.1016/j.jhazmat.2006.07.049

[5] Vadivelan V, Kumar KV. Equilibrium, kinetics, mechanism, and process design for the sorption of methylene blue onto rice husk. J Colloid Interface Sci 2005; 286: 90-100. http://dx.doi.org/10.1016/i.jcis.2005.01.007

[6] Ozer A, Dursun G. Removal of methylene blue from aqueous solution by dehydrated wheat bran carbon. J Hazard Mater 2007; 146: 262-69.

http://dx.doi.org/10.1016/j.jhazmat.2006.12.016 
[7] Abbasi M, AsI NR. Sonochemical degradation of Basic Blue 41 dye assisted by nanoTiO 2 and $\mathrm{H}_{2} \mathrm{O}_{2}$. J Hazard Mater 2008; 153: 942-7. http://dx.doi.org/10.1016/j.jhazmat.2007.09.045

[8] Sun J, Qiao L, Sun S, Wang G. Photocatalytic degradation and kinetics of Orange $\mathrm{G}$ using nano-sized $\mathrm{Sn}(\mathrm{IV}) / \mathrm{TiO}_{2} / \mathrm{AC}$ photocatalyst. J Hazard Mater 2008; 155: 312-19. http://dx.doi.org/10.1016/j.jhazmat.2007.11.062

[9] Lee JW, Choi SW, Thiruvenkatachari R, Shim WG, Moon H. Evaluation of the performance of adsorption and coagulation processes for the maximum removal of reactive dyes. Water Res 2006; 40: 435-44.

http://dx.doi.org/10.1016/j.watres.2005.11.034

[10] Maleki A, Mahvi AH, Ebrahimi R, Zandsalimi Y. Study of photochemical and sonochemical processes efficiency for degradation of dyes in aqueous solution. Korean $\mathrm{J}$ Chem Eng 2010; 27: 1805-10. http://dx.doi.org/10.1007/s11814-010-0261-0

[11] Neelavannan MG, Revathi M, Ahmed Basha C. Photocatalytic and electrochemical combined treatment of textile wash water. J Hazard Mater 2007; 149: 371-78.

http://dx.doi.org/10.1016/j.jhazmat.2007.04.025

[12] Pajootan E, Arami M, Mahmoodi NM. Binary system dye removal by electrocoagulation from synthetic and real colored wastewaters. J Taiwan Inst Chem Eng 2012; 43(2): 282-90.

http://dx.doi.org/10.1016/j.jtice.2011.10.014

[13] Garcia-Montano J, Ruiz N, Munoz I, et al. Environmental assessment of different photo-Fenton approaches for commercial reactive dye removal. J Hazar Mater 2006; 138: 218-25. http://dx.doi.org/10.1016/j.jhazmat.2006.05.061

[14] Arslan-Alaton I. Pretreatment of textile dye carriers with ozonation and enhanced ozonation. Environ Eng Sci 2004; 21: 507-14.

http://dx.doi.org/10.1089/1092875041358539

[15] Hou W, Xingzhong Y, Yan W, Huajaun H, Guangming Z, Yan Li, Xueli W, Ningbo L, Yu Q, Adsorption characteristics and behaviors of graphene oxide for $\mathrm{Zn}$ (II) removal from aqueous solution. Appl Surf Sci 2013; 279: 432-40.

http://dx.doi.org/10.1016/j.apsusc.2013.04.133

[16] Rahchamani J, Zavvar Mousavi H, Behzad M. Adsorption of methyl violet from aqueous solution by polyacrylamide as an adsorbent: Isotherm and kinetic studies. Desalination 2011; 267: 256-60.

http://dx.doi.org/10.1016/j.desal.2010.09.036

[17] Yi J, Zhang L. Removal of methylene blue dye from aqueous solution by adsorption onto sodium humate/polyacrylamide/ clay hybrid hydrogels. Bioresource Tecnol 2008; 99(7): 218286. http://dx.doi.org/10.1016/j.biortech.2007.05.028

[18] Hasan M, Ahmad AL, Hameed BH, Adsorption of reactive dye onto cross-linked chitosan/oil palm ash composite beads. Chem Eng J 2008; 136(2-3): 164-72.

[19] Shih MC. Kinetics of the batch adsorption of methylene blue from aqueous solutions on to rice husk: effect of acidmodified process and dye concentration. Desal Wat Treat 2010; 37: 200-14.

http://dx.doi.org/10.1080/19443994.2012.661273

[20] Hameed BH, Hakimi H. Utilization of durian (Duriozibethinus Murray) peel as low cost sorbent for the removal of acid dye from aqueous solutions. Biochem Eng J 2008; 39: 338-43. http://dx.doi.org/10.1016/j.bej.2007.10.005

[21] Hameed BH, El-Khaiary MI. Malachite green adsorption by rattan sawdust: Isotherm, kinetic and mechanism modeling. J Hazard Mater 2008; 159: 574-79.

http://dx.doi.org/10.1016/j.jhazmat.2008.02.054

[22] Yan C, Wang C, Yao J, Zhang L, Liu X. Adsorption of methylene blue on mesoporous carbons prepared using acid- and alkaline-treated zeolite $\mathrm{X}$ as the template. Colloids Surf A 2009; 333: 115-19.

http://dx.doi.org/10.1016/j.colsurfa.2008.09.028

[23] Badii K, Amini FL, Rasoli SS. Effect of surface morphology of macro-scale perlite particles on adsorption process of malachite green dye. Desal Wat Treat 2011; 28: 12-16. http://dx.doi.org/10.5004/dwt.2011.2193

[24] Sadaf S, Bhatti HN. Batch and fixed bed column studies for the removal of Indosol Yellow BG dye by peanut husk. J Taiwan Inst Chem Eng 2013; In Press, Corrected Proof.

[25] Almeida CAP, Debacher NA, Downs AJ, Cottet L, Mello CAD. Removal of methylene blue from colored effluents by adsorption on montmorillonite clay. J Colloid Interface Sci 2009; 332: 46-53.

http://dx.doi.org/10.1016/.j.jcis.2008.12.012

[26] Mckay G, Hadi M, Samadi MT, Rahmani AR, Aminabad MS, Nazemi F. Adsorption of reactive dye from aqueous solutions by compost. Desal Wat Treat 2011; 28: 164-73. http://dx.doi.org/10.5004/dwt.2011.2216

[27] Pan B, Pan B, Zhang W, Lv L, Zhang Q, Zheng S Development of polymeric and polymer-based hybrid adsorbents for pollutants removal from waters. Chem Eng $\mathrm{J}$ 2009; 151: 19-29.

http://dx.doi.org/10.1016/j.cej.2009.02.036

[28] Bajpai SK, Navin Ch, Mahendra M. The adsorptive removal of cationic dye from aqueous solution using poly (methacrylic acid) hydrogels: Part-I. equilibrium studies. Int J Environ Sci 2012; 2(3): 1609-24.

[29] Senkal BF, Yavuz E. Preparation of poly(vinylpyrrolidone) grafted sulfonamide based polystyrene resin and its use for the removal of dye from water. Polym Adv Technol 2007; 17: 928-31. http://dx.doi.org/10.1002/pat.837

[30] Zendehdel M, Barati A, Alikhani H, Hekmat A. Removal of methylene blue dye from wastewater by adsorption onto semi-inpenetrating polymer network composed of acrylamide and acrylic acid copolymer and polyvinyl alcohol. Iranian J Environ Health Sci Eng 2010; 7: 431-36.

[31] Zhao Y, Chen Y, Li M, Zhou S, Xue A, Xing W. Adsorption of $\mathrm{Hg}^{2+}$ from aqueous solution onto polyacrylamide/attapulgite. J Hazard Mater 2009; 171: 640-46.

http://dx.doi.org/10.1016/j.jhazmat.2009.06.048

[32] Zhou S, Xue A, Zhao Y, et al. Competitive adsorption of $\mathrm{Hg}^{2+}$, $\mathrm{Pb}^{2+}$ and $\mathrm{Co}^{2+}$ ions on polyacrylamide/attapulgite. Desalination 2011; 270: 269-74. http://dx.doi.org/10.1016/j.desal.2010.11.055

[33] Paulino AT, Guilherme MR, Reis AV, Campese GM, Muniz EC, Nozaki J. Removal of methylene blue dye from an aqueous media using superabsorbent hydrogel supported on modified polysaccharide. J Colloid Interface Sci 2006; 301: 55-62. http://dx.doi.org/10.1016/j.jcis.2006.04.036

[34] Alkan M, Dogan M. Adsorption kinetics of Victoria blue onto perlite. Fresen Environ Bull 2003; 12: 418-25.

[35] Bouberka Z, Kacha S, Kameche M, Elmaleh S, Derriche Z. Sorption study of an acid dye from aqueous solutions using modified clays. J Hazard Mater 2005; 119: 117-24. http://dx.doi.org/10.1016/i.jhazmat.2004.11.026

[36] Alkan M, Celikçapa S, Demirbas O, Dogan M. Removal of reactive Blue from aqueous solutions by sepiolite. Dyes Pigm 2005; 65: 251-54. http://dx.doi.org/10.1016/j.dyepig.2004.07.018

[37] Langmuir I. The adsorption of gases on plane surfaces of glass mica and platinum. J Am Chem Soc 1918; 40: 1361403.

http://dx.doi.org/10.1021/ja02242a004

[38] Hall KR, Eagleton LC, Acrivos A, Vermeulen T. Pore and solid diffusion kinetics in fixed-bed adsorption under 
constant-pattern conditions. Ind Eng Chem Fundam 1966; 5: 212-23.

http://dx.doi.org/10.1021/i160018a011

[39] Freundlich HMF. Over the adsorption in solution. J Phys Chem 1906; 57: 385-70.

[40] Namasivayam C, Jeyakumar R, Yamuna RT. Dye removal from waste water by adsorption on waste $\mathrm{Fe}(\mathrm{III}) / \mathrm{Cr}$ (III)hydroxide. Waste Manage 1994; 14: 709-16. http://dx.doi.org/10.1016/0956-053X(94)90058-2

[41] Temkin MJ, Pyzhev V. Recent modifiications to Langmuir isotherms. Acta Physiochim Ussr 1940; 12: 217-22.

[42] Kim Y, Kim C, Choi I, Rengraj S, Yi J. Arsenic removal using mesoporous alumina prepared via a templating method. Environ Sci Technol 2004; 38: 924-31. http://dx.doi.org/10.1021/es0346431

[43] Vilar VJP, Botelho CMS, Boaventura RAR. Methylene blue adsorption by algal biomass based materials: Biosorbents characterization and process behavior. J Hazard Mater 2007; 147: 120-32. http://dx.doi.org/10.1016/j.jhazmat.2006.12.055

[44] Hajjaji M, Alami A, El Bouadili A. Removal of methylene blue from aqueous solution by fibrous clay minerals. J Hazard Mater 2006; 135: 188-92.

http://dx.doi.org/10.1016/j.jhazmat.2005.11.048

[45] Annadurai $G$, Juang RL, Lee DJ. Use of cellulose-based wastes for adsorption of dyes from aqueous solutions. J Hazard Mater 2002; 92: 263-74. http://dx.doi.org/10.1016/S0304-3894(02)00017-1

[46] Weng $\mathrm{CH}$, Pan YF. Adsorption of a cationic dye (methylene blue) onto spent activated clay. J Hazard Mater 2007; 144: 355-62. http://dx.doi.org/10.1016/j.jhazmat.2006.09.097

[47] Liang J, Wu J, Li P, Wang X, Yang B. Shaddock peel as a novel low-cost adsorbent for removal of methylene blue from dye wastewater. Desal Wat Treat 2012; 39: 70-75. http://dx.doi.org/10.1080/19443994.2012.669160
[48] Kavitha D, Namasivayam C. Experimental and kinetic studies on methylene blue adsorption by coir pith carbon. Bioresour Technol 2007; 98: 14-21. http://dx.doi.org/10.1016/j.biortech.2005.12.008

[49] Zhou Q, Gong W, Xie C, et al. Biosorption of methylene blue from aqueous solution on spent cottonseed hull substrate for Pleurotus ostreatus cultivation. Desal Wat Treat 2011; 29 : 317-25.

http://dx.doi.org/10.5004/dwt.2011.2238

[50] Malana MA, ljaz S, Ashiq MN. Removal of various dyes from aqueous media onto polymeric gels by adsorption process: Their kinetics and thermodynamics. Desalination 2010; 263(1-3): 249-57.

http://dx.doi.org/10.1016/j.desal.2010.06.066

[51] Saraydin D, Karadug E, Guven O. Adsorption of some basic dyes to acrylamide-maleic acid hydrogels. J Sep Sci Technol 1996; 31: 423-33. http://dx.doi.org/10.1080/01496399608000705

[52] Liu P, Guo J. Polyacrylamide grafted attapulgite (PAM-ATP) via surface initiatedatom transfer radical polymerization (SIATRP) for removal of $\mathrm{Hg}$ (II) ion and dyes. Colloids Surf $\mathrm{A}$ 2006; 282-283: 498-503. http://dx.doi.org/10.1016/j.colsurfa.2006.02.052

[53] Lagergren S. About the theory of so-called adsorption of soluble substance. Kung Sven Veten Hand1898; 24: 1-39.

[54] Ho YS, Mckay G. Pseudo-Second. Order Model for Sorption Processes. Process Biochem 1999; 34: 451-65. http://dx.doi.org/10.1016/S0032-9592(98)00112-5

[55] Weber WJ, Morris JC, Sanit J. Kinetics of adsorption on carbon from solution. Eng Div Am Soc Civ Eng 1963; 89: 3160.

[56] Nollet H, Roels M, Lutgen P, Van der Meeren P, Verstraete W. Removal of PCBs from wastewater using fly ash. Chemosphere 2003; 53: 655-65.

http://dx.doi.org/10.1016/S0045-6535(03)00517-4 